\title{
Influence of Different Promoters on the Expression Pattern of Mutated Human a-Synuclein in Transgenic Mice
}

\author{
Lyutha Maskria XinRan Zhu ${ }^{a}$ Sabrina Fritzen ${ }^{a}$ Kati Kühn ${ }^{a}$ \\ Christoph Ullmer $^{b}$ Peter Engels $^{b}$ Michael Andriske ${ }^{a}$ Christine C. Stichel $^{b}$ \\ Hermann Lübbert ${ }^{a, b}$ \\ ${ }^{a}$ Animal Physiology, Ruhr University Bochum, Bochum and ${ }^{b}$ Biofrontera Pharmaceuticals $\mathrm{GmbH}$, \\ Leverkusen, Germany
}

\section{Key Words}

Parkinson's disease $\cdot$ Promoter activity $\cdot$ Nigrostriatal system $\cdot \alpha$-Synuclein $\cdot$ Transgene

\begin{abstract}
Two missense mutations (A53T and A30P) in the gene encoding the presynaptic protein $\alpha$-synuclein (asyn) are associated with rare, dominantly inherited forms of Parkinson's disease (PD) and its accumulation in Lewy bodies and Lewy neurites. As an initial step in investigating the role of asyn in the pathogenesis of $P D$, we have generated $\mathrm{C} 57 \mathrm{BL} / 6$ transgenic mice overexpressing the doubly mutated human asyn under the control of three different promoters; the chicken $\beta$-actin (ch $\beta$ actin), the mouse tyrosine hydroxylase $9.6 \mathrm{~kb}(\mathrm{msTH})$ and the mouse prion protein (msprp). In this study we compared the regional and cellular expression pattern of the transgenic protein in the brain and peripheral organs of various transgenic mouse lines. Western blot analysis and immunohistochemistry consistently showed that all three promoters successfully drive the expression of the transgene. The msprp promoter was found to give the highest level of transgene expression. All promoters directed the expression into the brain and specific neu-
\end{abstract}

L.M. and X.Z. both contributed equally.

\section{KARGER}

Fax +41613061234

E-Mail karger@karger.ch

www. karger.com
(C) 2004 S. Karger AG, Basel

$1660-2854 / 04 / 0016-0255 \$ 21.00 / 0$

Accessible online at:

www. karger.com/ndd ron types. However, the promoters differed with respect to (i) the expression pattern in peripheral organs, (ii) the number and (iii) the regional distribution of expressing cells in the brain. Furthermore, remarkable line-to-line variation of expression patterns was observed in mouse lines carrying the same construct. Future studies will analyze how the variations in transgene expression affect the pathogenesis in the animals.

Copyright (c) 2004 S. Karger AG, Basel

\begin{tabular}{ll}
\hline Abbreviations \\
\hline $\begin{array}{l}\text { asyn } \\
\text { ch }\end{array}$ & $\begin{array}{l}\alpha \text {-synuclein } \\
\text { chicken }\end{array}$ \\
CMV-IE & $\begin{array}{l}\text { cytomegalovirus enhancer } \\
\text { E }\end{array}$ \\
exon \\
hAD & glutamic acid decarboxylase \\
hm 2 asyn & human \\
LM & littermate $\alpha$-synuclein with two point mutations \\
ms & mouse \\
PBS & phosphate-buffered saline \\
prp & prion protein \\
SA & splice acceptor \\
SD & splice donor \\
SV40 & simian virus 40 \\
TG & transgenic \\
TH & tyrosine hydroxylase
\end{tabular}




\section{Introduction}

a-Synuclein (asyn), first isolated in 1988 from synaptic vesicles of Torpedo californica and rat brain [1], is a member of a protein family consisting of $\alpha-, \beta$-, and $\gamma$-synuclein $[2,3]$. It is a small 140-aa protein that is abundantly expressed in the brain and highly enriched in presynaptic vesicles $[1,4]$. Linkage of the PARK1 locus on chromosome $4 \mathrm{q} 21$, where the asyn gene is located, to autosomal dominant Parkinson's disease (PD) in a large Greek family [5] suggested that asyn might be implicated in the pathogenesis of PD. Recent studies have supported this hypothesis, showing that (i) three missense mutations resulting in an Ala53Thr (A53T) [6], an Ala30Pro (A30P) [7] or an E64K [8] exchange, respectively, as well as a triplication of the entire wild-type gene [9] are associated with familial forms of PD, (ii) asyn protein is the most abundant component of Lewy bodies [10, 11] and (iii) a polymorphism in the $5^{\prime}$-untranslated region of the asyn gene correlates with an increased PD risk [12].

However, the question remains which role asyn plays in the pathogenesis of PD. Animal models based on the transgenic (TG) expression of wild-type and mutated genes provide powerful tools to elucidate the functional role of the encoded proteins. Hence, to date, several TG animals overexpressing either wild-type or mutant human asyn have been generated [13-24]. Unfortunately, the asyn transgenic lines (asynTG) exhibited different phenotypes and none of them replicated the complete PD pathology. This phenotypic inconsistency is likely caused by the different promoters used to drive transgene expres- sion, by different integration sites and/or by different levels of transgene expression.

To elucidate the role of the promoter on the expression pattern of a transgene, we generated several synTG lines in which the expression of the doubly mutated human asyn ( $\mathrm{hm}^{2}$ asyn) is driven by three different promoters. We used the chicken $\beta$-actin (ch $\beta$ actin) promoter, the $9.6-\mathrm{kb}$ mouse tyrosine hydroxylase (msTH) promoter, and the mouse prion protein (msprp) promoter. In several synTG mouse lines from each promoter construct, we compared the regional and cellular expression of the transgene in the brain and peripheral organs.

\section{Materials and Methods}

Construction of $\mathrm{hm}^{2}$ asyn TG Animals

For the present study we generated TG mice expressing $\mathrm{hm}^{2}$ asyn under the control of three different promoters: the $\operatorname{ch} \beta$ actin, the $\mathrm{msTH}$, and the msprp promoter.

Human asyn cDNA was obtained by RT-PCR. The two PD-associated mutations were introduced by in vitro mutagenesis (Quickchange kit; Stratagene, Calif., USA). To maintain SV40 SD/SA and polyA elements, the mutated cDNA was ligated into the vector pCMV- $\beta$ (Clontech, Calif., USA) after restriction with XhoI and removal of the overhanging ends by treatment with the Klenow fragment of DNA polymerase I. The cDNA with the adjacent SV40 elements was separated from the vector by restriction with $X b a \mathrm{I}$.

For the overexpression with the ch $\beta$ actin promoter the $\mathrm{hm}^{2}$ asyn cDNA was cloned into the XhoI site of the vector pCAGGS (Gunma University School of Medicine, Japan). Due to the rb $\beta$-globin polyA and CMV-IE enhancer in this vector, the asyn cDNA was inserted without the SV40 elements (fig. 1).
Fig. 1. Schematic representation of the chßactin, the msTH and the msprp construct. CMV-IE, cytomegalovirus enhancer promoter; E1-E3: exon 1-exon 3; SD/SA: splice donor/splice acceptor; SV40: Simian virus-40.

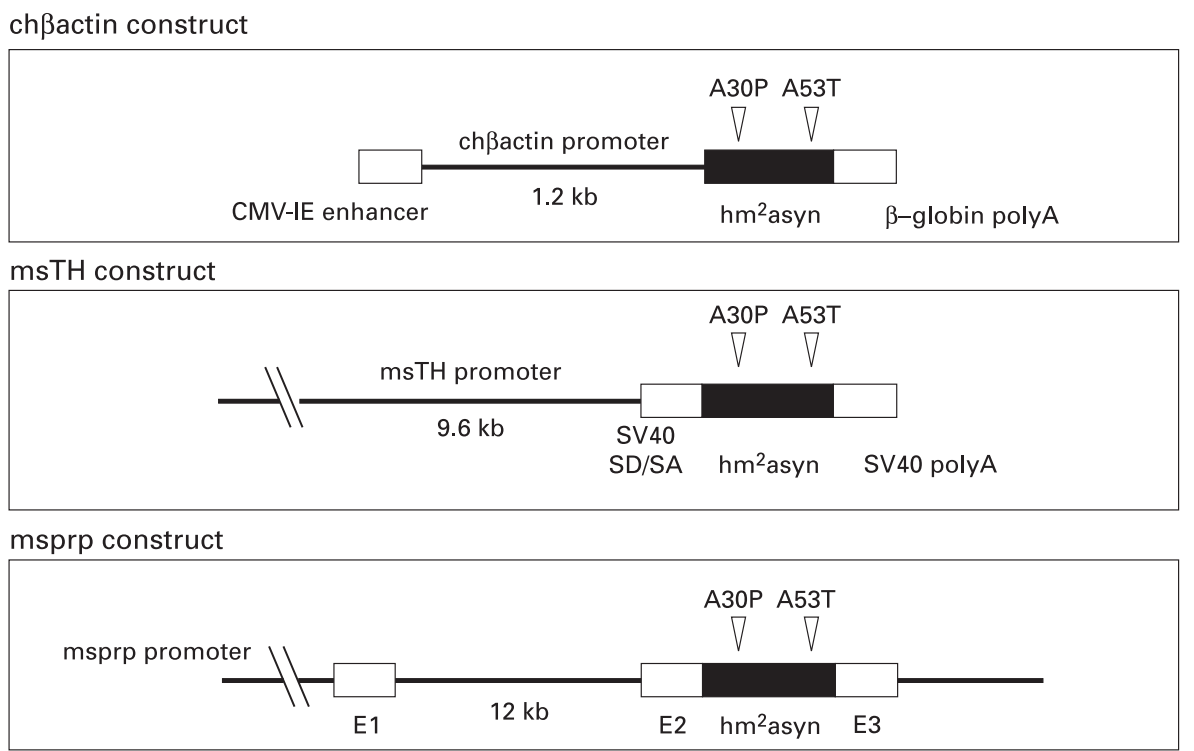


A 9.6-kb region of the msTH promoter (Genbank accession No. ACO12382) was cloned using several subclones of BAC clone 266D14 (restriction sites EcoRV and XhoI). The 815-bp fragment between the ATG and XhoI restriction site was amplified by PCR (primer THPRs: CCAGCTGAGAATGGGGGCTGCC, THPRas1: TCTAGAGCTCCTCCTCCCGAGTTCTG). The PCR fragment was analyzed for correct sequence and cloned into pBluescript $\mathrm{KS}(+)$ together with the promoter. The $\mathrm{hm}^{2}$ asyn with the SV40 elements was integrated by restriction with $X b a \mathrm{I}$ (fig. 1).

For the msprp construct, the hm²asyn cDNA was inserted into vector msPrP.XhoI (Johns Hopkins University, Md., USA) by restriction with $X$ hoI without the adjacent SV40 elements (fig. 1).

All constructs were sequenced and introduced into the germ line of C57 BL/6 mice by pronuclear injection of one-cell mouse embryos. Founders and offspring were identified by Southern blot and PCR analysis of tail DNA. TG mice were bred by crossing them with mouse strain C57BL/6. For the different constructs the following number of founders/stably expressing lines were generated: msprp $3 / 2$, ch $\beta$ actin $10 / 3$ and msTH $5 / 3$. For all experiments, heterozygous TG and non-TG littermates (LM) were used. Animals were housed and maintained in accordance with the German guidelines of the animal care and use of laboratory animals.

\section{Transfections}

COS-1 cells (ATCC No. CRL-1650) cultured in growth medium, DMEM (Invitrogen, San Diego, Calif., USA), supplemented with $10 \%$ FBS (Invitrogen) in a humidified chamber with $8 \% \mathrm{CO}_{2}$, were seeded into $6-\mathrm{cm}$ plates 1 day prior to transfection. Transfections with the constructs were performed by using the Lipofectamine Plus reagent (Invitrogen) according to the manufacturer's instructions. The following day cells were seeded into $10-\mathrm{cm}$ plates and grown until confluence for another 48 or $72 \mathrm{~h}$. Cells were scraped off in $\mathrm{Ca}^{2+}$-free phosphate-buffered saline (PBS; Invitrogen), collected by centrifugation, and washed twice in PBS. Pellets were frozen in liquid nitrogen and stored at $-80^{\circ} \mathrm{C}$ until use.

\section{Tissue Preparation}

The TG animals as well as the non-TG LMs were divided into two groups. One group for Western blot analysis was sacrificed by decapitation. Brain regions were dissected and stored at $-80^{\circ} \mathrm{C}$ until analysis. The other group was transcardially perfused with PBS followed by $4 \%$ paraformaldehyde (PA) in $0.1 M$ phosphate buffer.

For immunohistochemistry (ICC) perfusion-fixed brains were embedded in paraffin. Serial, frontal or sagittal, 5- or 18- $\mu \mathrm{m}$-thick sections were cut throughout the brain for each mouse. All sections were mounted on Superfrost slides (Roth, Germany).

\section{Protein Extraction and Immunoblots}

For immunoblotting, dissected mouse brain regions were homogenized in homogenization buffer $(0.32 M$ saccharose, 1 protease inhibitor tablet in $50 \mathrm{ml}$; Hoffmann-La Roche, Switzerland) containing complete protease inhibitor cocktail (Boehringer Mannheim, Germany) using Teflon/glass homogenizer at $4{ }^{\circ} \mathrm{C}$. Homogenized samples were left on ice for $30 \mathrm{~min}$ and centrifuged at 13,200 rpm $(16,400 \mathrm{~g})$ in a precooled centrifuge. The supernatant was diluted 1:1 in $2 \times$ Laemmli sample buffer and boiled. Protein determination was performed by the method of Neuhoff et al. [25].

Proteins were electrophoretically separated (15-30 $\mu \mathrm{g}$ protein/ lane) on a $15 \%$ polyacrylamide gel-containing sodium dodecyl sulfate and transferred onto polyvinylidene difluoride membranes (Milli- pore, UK) at $4{ }^{\circ} \mathrm{C}$ with $200 \mathrm{~mA}$ for $1.5 \mathrm{~h}$. Blocking was performed with $3 \%$ milk powder and $2 \%$ bovine serum albumin in TBS-Tween $(0.1 \%$ Tween, $20 \mathrm{~m} M$ TBS) at room temperature (RT) for $1 \mathrm{~h}$. First, the membranes were incubated with an antibody against human asyn (Syn211, 1:1,000, diluted in blocking buffer; Zymed, Germany) overnight at $4{ }^{\circ} \mathrm{C}$, followed by washing in TBS-Tween and a second incubation with HRP-coupled secondary antibody $(1: 10,000$; Amersham, Germany) in $1 \%$ milk powder, $0.5 \%$ bovine serum albumin in TBSTween at RT for $1.5 \mathrm{~h}$. The blots were washed and developed using the ECL-Plus system (Amersham, Germany). After detection, the membranes were stripped with Restore stripping buffer (Pierce, Ill., USA) for $10 \mathrm{~min}$ at RT, incubated with a monoclonal antibody against $\beta$-actin (1:1,000; Sigma, Germany) and processed for detection as described above.

Films were digitized using a Cannon Power Shot Pro70 camera and analyzed using ImagePro software. Mean relative optical density in fixed measurement frames over the band of interest was corrected for background and protein content (corresponding $\beta$-actin band).

\section{Immunohistochemistry}

Deparaffinized and rehydrated sections were used for immunohistochemistry. Antigen retrieval (5-min cooking in $0.01 \mathrm{M}$ citrate buffer $\mathrm{pH}$ 6.0) was performed with all sections. To reduce nonspecific binding, incubation sections were treated with 3\% normal serum in $0.01 \mathrm{M}$ PBS for $10 \mathrm{~min}$ by RT prior to antisera incubation.

Expression of $\mathrm{hm}^{2}$ asyn protein was analyzed with a monoclonal antibody specific for hmasyn (Syn211, 1:500). Following the first antiserum incubations, sections were treated by the corresponding biotinylated secondary antibody, $\mathrm{ABC}$ reagent and a silver-gold intensification [26]. Specificity of the stainings was confirmed by omitting primary antibodies.

For co-localization of $\mathrm{hm}^{2}$ asyn and the neurotransmitters dopamine and $\gamma$-aminobutyric acid, 5 - $\mu \mathrm{m}$-thick adjacent sections were either incubated with Syn 211 or a sheep polyclonal antiserum against sheep tyrosine hydroxylase (TH, 1:500; Chemicon, Germany) and a monoclonal antibody against mouse glutamic acid decarboxylase (GAD, 1:5,000; Affinity, UK), respectively. Following, sections were processed as described above.

\section{Data Analysis}

Brain sections were visualized at the microscopic level (Axioscop 2; Zeiss, Germany) under brightfield illumination. Structures were described according to the main subdivisions of the brain and were identified with the aid of the atlas of Paxinos and Franklin [27]. Images were captured with an imaging system (Sony MC3255 camera) connected to a computer equipped with an image program (KS100 Rel.3.0). For final output, images were processed using Photoimpact 4 software.

\section{Results}

Three different promoters were tested for the expression of doubly mutated $\alpha$-synuclein $\left(\mathrm{hm}^{2} \mathrm{asyn}\right)$ in the mouse brain. Lines transmitting the transgene to offsprings were analyzed by Western blot analysis and immunohistochemistry for differences in regional and cellular expression patterns. No TG line showed loss of neu- 


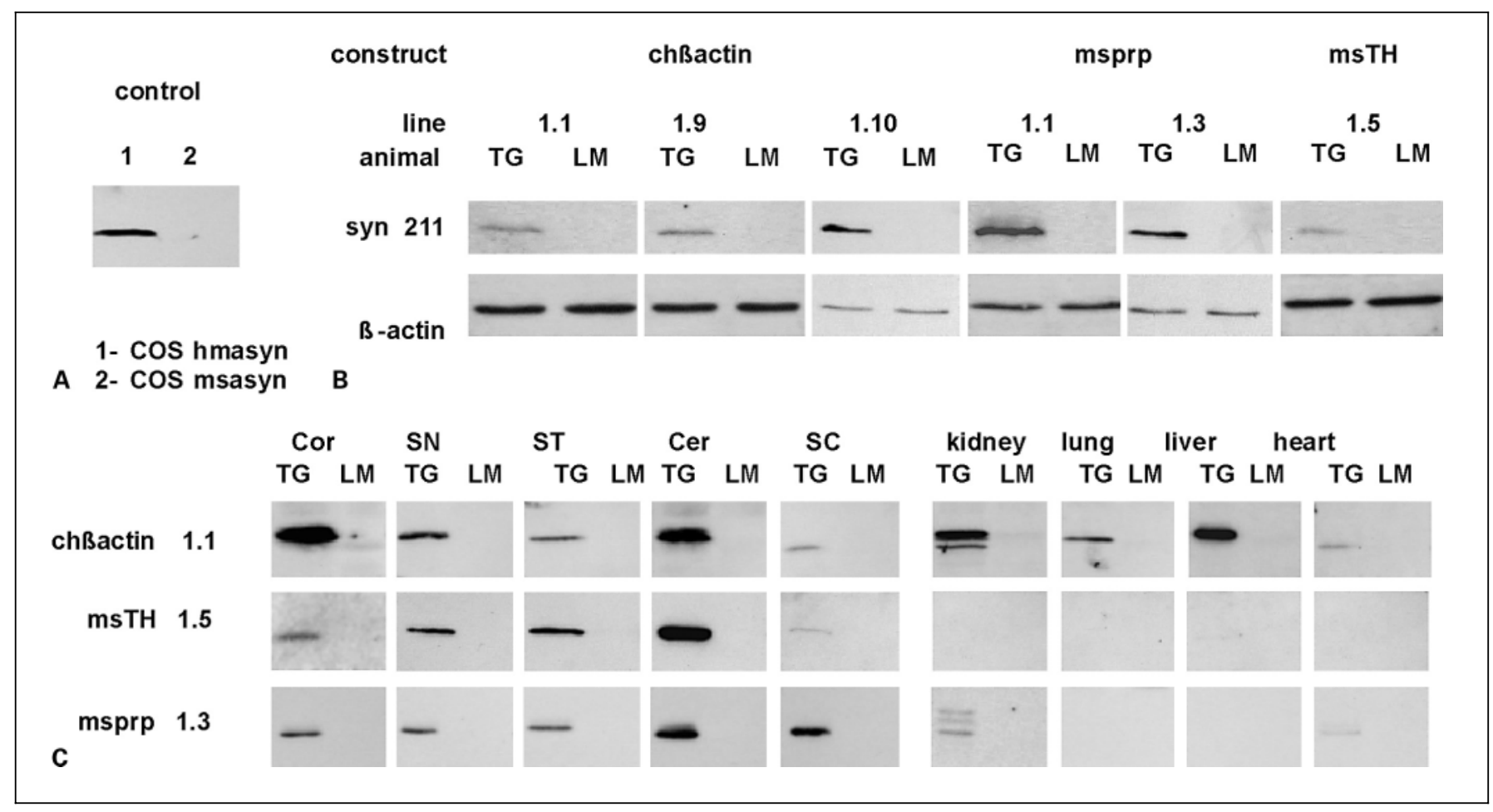

Fig. 2. Western blot analysis probed with human-specific asyn antibody (Syn211). A The Syn211-antibody is specific for human asyn, as shown by the strong band at about $16 \mathrm{kD}$ in the COS cells transfected with human asyn (1) and the absence of labeling in the COS cells transfected with mouse asyn (2). B, C Protein extracts of total brain (B, $20 \mu \mathrm{g}$ protein/lane), different brain regions (C, chßactin 1.1 and $\mathrm{msTH} 1.5-30 \mu \mathrm{g}$ protein/lane; msprp 1.3-15 $\mu \mathrm{g}$ protein/lane) and peripheral organs (C, $20 \mu \mathrm{g}$ protein/lane) of 2- to 4-month-old TG mice were incubated with Syn211. Blots shown in B were stripped and probed with an antibody against $\beta$-actin to check for equal loading. Note (i) the difference in expression levels in total brain, (ii) the absence of $\mathrm{hm}^{2}$ asyn expression in the kidney, the lung, the liver and the heart of the msTH-driven TGs, (iii) the kidneyspecific appearance of an asyn fragment in the chßactin line 1.1 and (iv) the higher molecular weight forms of asyn displayed by the kidney of the msprp line 1.3. Cer = Cerebellum; Cor = cortex; $\mathrm{SC}=$ spinal cord; $\mathrm{SN}=$ substantia nigra; $\mathrm{ST}=$ striatum. rons in the substantia nigra compacta. However, the msTH lines developed mitochondrial changes at the age of 2 months (data not shown).

\section{Localization of the TG Protein in Mouse Tissues}

Using Western blot analysis, we analyzed the expression levels and regional distribution patterns of the transgene in different organs of one line for each construct. To specifically detect $\mathrm{hm}^{2}$ asyn we used the monoclonal antibody Syn211. Western blot analysis of COS-1 cells transfected with either human or mouse asyn (fig. 2A) and immunohistochemistry of wild-type mouse tissue (fig. 4F, and see below) demonstrated the specificity of Syn 211 for human asyn with no cross-reactivity to mouse asyn.

All TG lines expressed the $\mathrm{hm}^{2}$ asyn in the brain and only the chßactin and the msprp lines showed expression in peripheral organs.
In total brain, lines with the msprp construct showed the highest level of expression (fig. 2B), about four times higher than that induced by the $\mathrm{ch} \beta$ actin and $\mathrm{msTH}$ promoters.

All constructs induced transgene expression in several brain regions (fig. 2C). The level of expression varied among the different brain regions, but was always strongest in the cerebellum.

With respect to peripheral organs, animals with the chßactin construct displayed a strong band in the kidney and the liver, while lung and heart displayed only moderate levels of the transgene (fig. 2C). The msprp construct induced some faint expression in the kidney and the heart, while in the msTH animals the transgene expression was restricted to the brain and spinal cord (fig. 2C). 


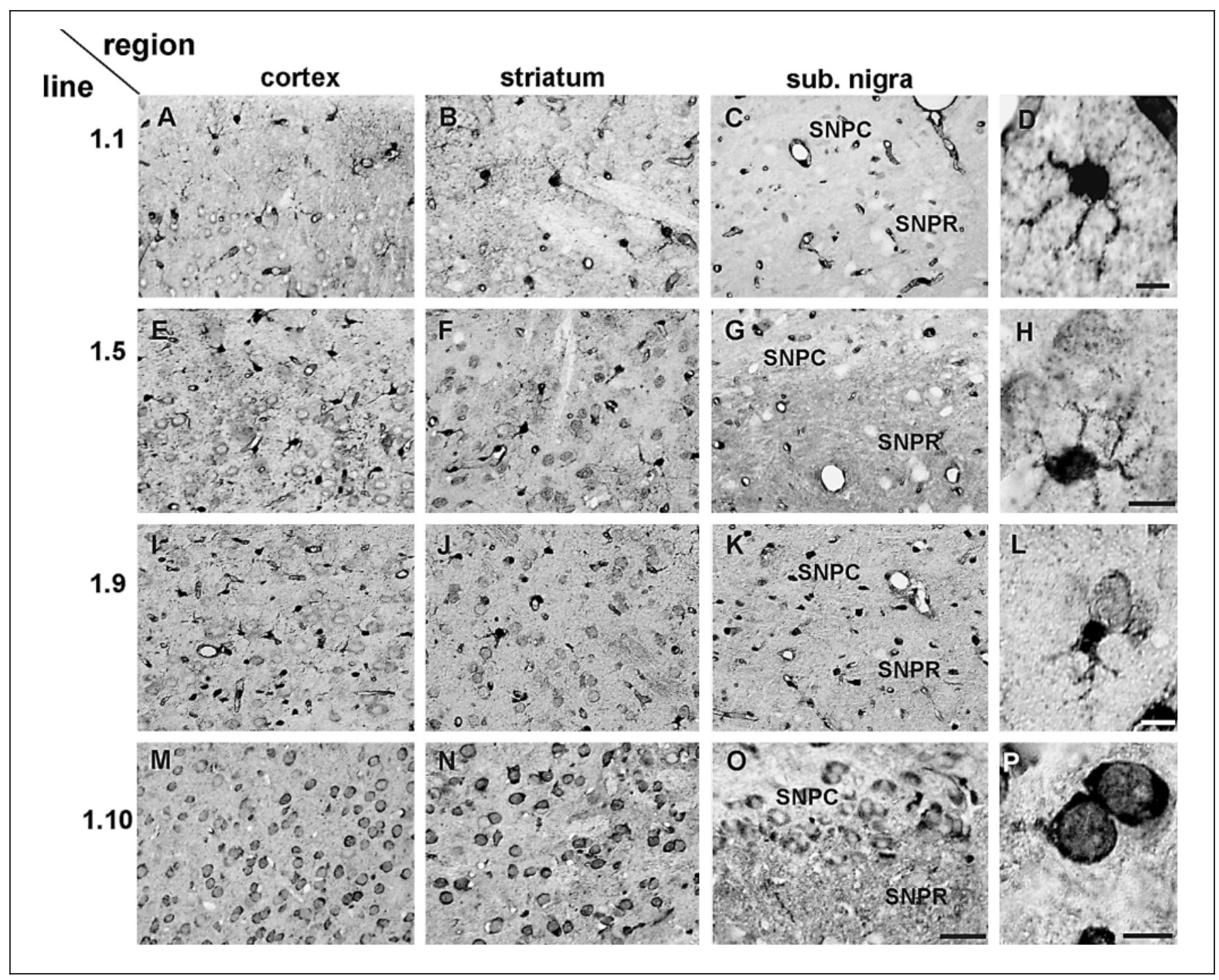

Fig. 3. ch $\beta$ actin lines. Expression of $\mathrm{hm}^{2}$ asyn protein in ch $\beta$ actin line 1.1 (A-D), line 1.5 (E-H), line $1.9(\mathbf{I}-\mathbf{L})$ and line $1.10(\mathbf{M}-\mathbf{P})$ at the age of 4-6 weeks. All lines expressing the $\mathrm{hm}^{2}$ asyn protein under the control of $\mathrm{ch} \beta$ actin promoter exhibit numerous immunopositive cells in the cortex, the striatum and the substantia nigra. While lines 1.1, 1.5 and 1.9 show neuronal as well as glial labeling $(\mathbf{D}, \mathbf{H}, \mathbf{L})$, only neurons were stained in the line $1.10(\mathbf{P})$. Note that the latter also displays staining of the dopaminergic neurons in the substantia nigra pars compacta. SNPC = Substantia nigra pars compacta; SNPR = substantia nigra pars reticulata. Scale bars, $250 \mu \mathrm{m}(\mathbf{O}$, also for $\mathbf{A}-\mathbf{C}$, E-G, I-K, M, N); $100 \mu \mathrm{m}(\mathbf{D}, \mathbf{L}) ; 50 \mu \mathrm{m}(\mathbf{H}, \mathbf{P})$.

\section{Transgene Expression Pattern in the Brain}

The patterns of hmasyn protein in the brain were investigated in four chßactin-hm²asyn, two msTH$\mathrm{hm}^{2}$ asyn and two msprp-hm²asyn lines. All lines showed transgene expression throughout the brain, but both the regional expression level and the cells expressing the transgene varied among the different constructs. Moreover, we also observed that lines carrying the same construct exhibit differences in expression patterns.
Regional Expression Pattern

While the chßactin promoter induced high levels of $\mathrm{hm}^{2}$ asyn in all brain divisions, the regional expression patterns of the four lines differed considerably from one another (fig. 3-5; table 1). In contrast to line 1.10, which exhibited strong expression in almost all brain regions analyzed, lines 1.1, 1.5 and 1.9 showed much lower expression levels (fig. 3, table 1). The most remarkable difference was observed in the nigrostriatal system. Only 

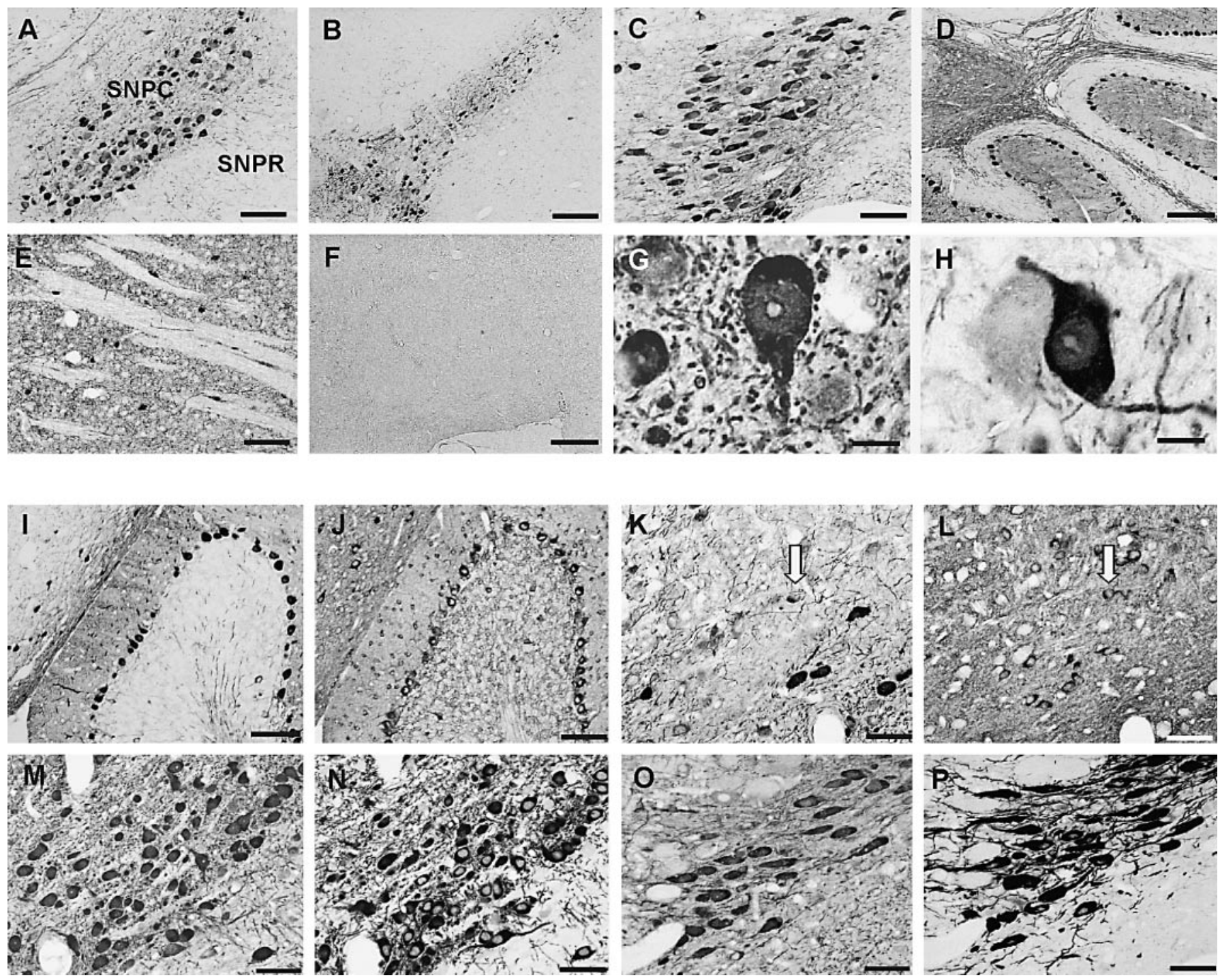

Fig. 4. $\mathrm{msTH}$ line 1.5. A-H Expression of $\mathrm{hm}^{2}$ asyn protein in 6week-old animals of msTH line 1.5. Strong immunostained neurons distributed in the substantia nigra (A), the retrorubral field (B), the locus coeruleus (C), the cerebellum (D) and the striatum (E). F NonTG littermate is free of immunoreactivity. G, $\mathbf{H}$ High magnification of neurons expressing $\mathrm{hm}^{2}$ asyn protein. I-P Staining of adjacent $5-\mu$ m-thick sections with $\operatorname{Syn} 211(\mathbf{I}, \mathbf{K}, \mathbf{M}, \mathbf{O})$ and $\operatorname{GAD}(\mathbf{J}, \mathbf{L})$ or
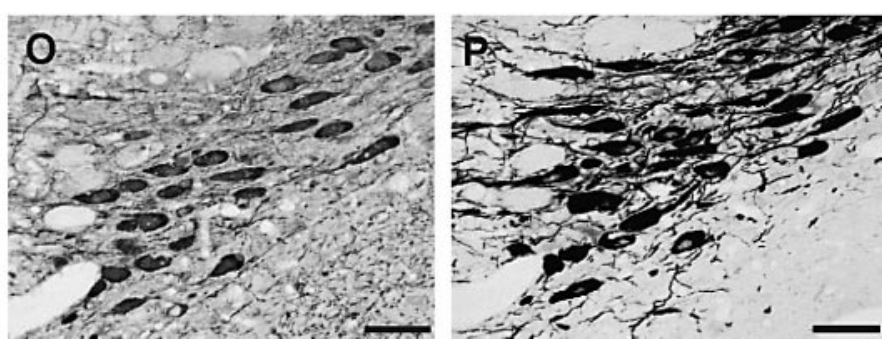

$\mathrm{TH}(\mathbf{N}, \mathbf{P})$. In the cerebellum $(\mathbf{I}, \mathbf{J})$ all Purkinje cells and various interneurons, and in the substantia nigra pars reticulata $(\mathbf{K}, \mathbf{L})$ single (marked by an arrow) gabaergic neurons express the $\mathrm{hm}^{2}$ asyn protein. Transgene expression is mostly found in catecholaminergic neurons, as shown here in the substantia nigra pars compacta $(\mathbf{M}, \mathbf{N})$ and the locus coeruleus $(\mathbf{O}, \mathbf{P})$. Scale bars, $500 \mu \mathrm{m}(\mathbf{A}, \mathbf{C}, \mathbf{E}, \mathbf{I}, \mathbf{J}) ; 1 \mathrm{~mm}$ (B, D, F); $50 \mu \mathrm{m}(\mathbf{G}, \mathbf{H}) ; 250 \mu \mathrm{m}(\mathbf{K}-\mathbf{P})$.

one of four lines (1.10) exhibited strong expression in the substantia nigra and the striatum (fig. 3, table 1). Moreover, the most abundant expression within this line was seen in the cerebral cortex, the hippocampus and the thalamus.

In contrast to the latter, the msTH promoter induced a more distinct expression pattern. The number of $\mathrm{hm}^{2}$ asyn-positive cells was much lower and the distribu- tion of expressing cells mirrored exactly the endogenous $\mathrm{TH}$ gene expression in the adult mouse and through development (fig. 4A-H, table 1). The latter relates to the fact that animals exhibited ectopic expression at several sites that express $\mathrm{TH}$ in the embryo but do not maintain expression in the adult such as the cerebellum (fig. 4D) and the inferior colliculus. In contrast to the $\operatorname{ch} \beta$ actin lines, the expression patterns were almost identical in the 

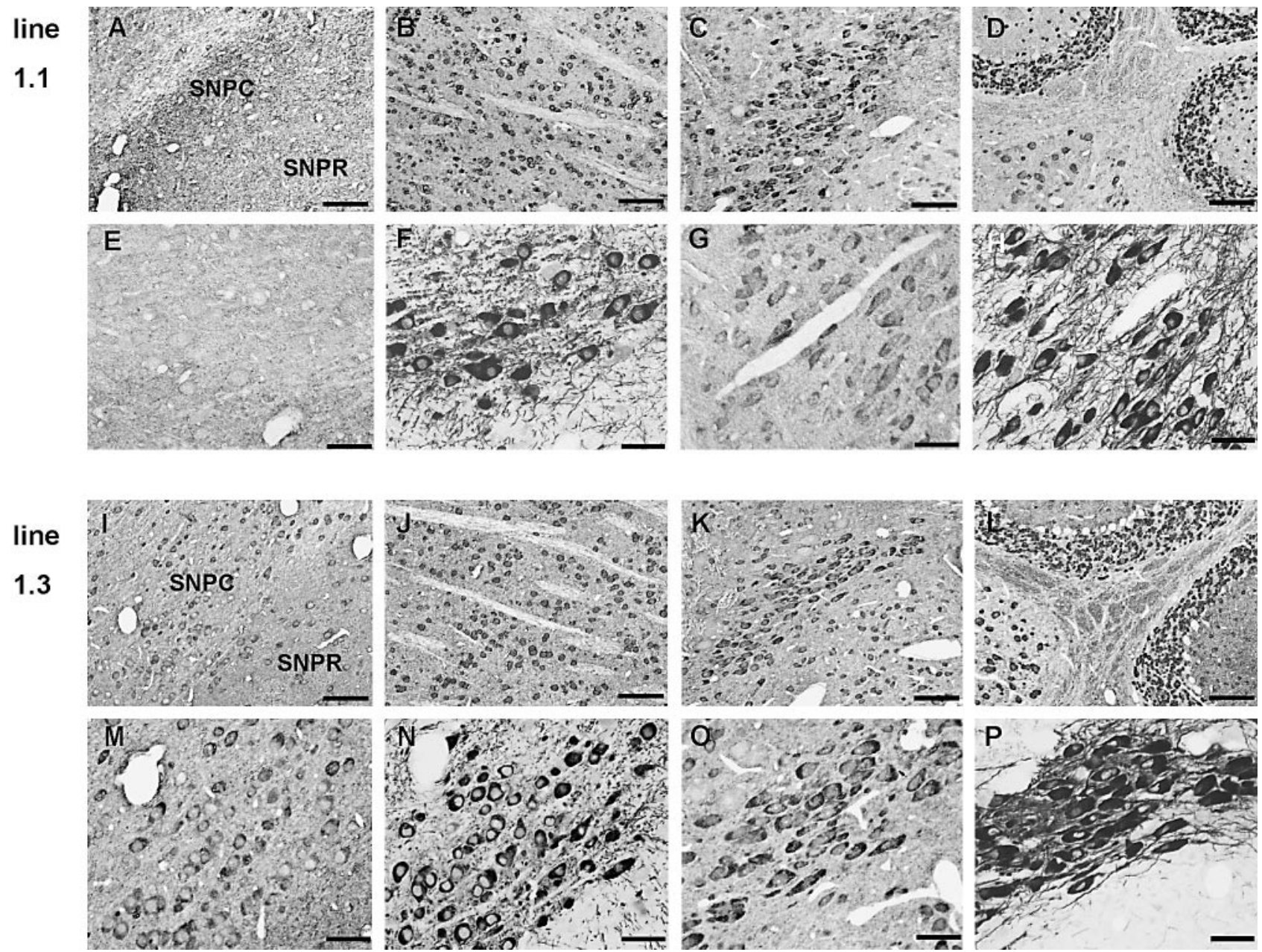

Fig. 5. msprp lines. A-D, I-L Expression of $\mathrm{hm}^{2}$ asyn protein in 4- to 8-week-old mice of lines 1.1 (A-D) and 1.3 (I-L). Both lines show numerous expressing neurons in the striatum $(\mathbf{B}, \mathbf{J})$, the locus coeruleus $(\mathbf{C}, \mathbf{K})$ and the cerebellum $(\mathbf{D}, \mathbf{L})$. In contrast to the substantia nigra of line 1.1 which is free of immunopositive cells (A, E), that of line 1.3 exhibits $\mathrm{hm}^{2}$ asyn protein-expressing neurons. E-H, M-P Staining of adjacent $5-\mu \mathrm{m}$-thick paraffin sections with $\operatorname{Syn} 211$ (E, G,
$\mathbf{M}, \mathbf{O})$ or TH $(\mathbf{F}, \mathbf{H}, \mathbf{N}, \mathbf{P})$ demonstrate the expression of $\mathrm{hm}^{2}$ asyn protein in catecholaminergic neurons of the substantia nigra in line 1.3 and of the locus coeruleus in lines 1.1 and 1.3. Note, that the dopaminergic neurons in the substantia nigra of line 1.1 do not express the transgene. Scale bars, $500 \mu \mathrm{m}$ (A-D, I-L); $250 \mu \mathrm{m}(\mathbf{E}-\mathbf{H}$, M-P). two msTH lines analyzed and differed only in few regions (table 1). In general, the highest expression levels were found in the mesencephalon, while the diencephalon was devoid of $\mathrm{hm}^{2}$ asyn-expressing cells.

The msprp construct favored a strong expression in all brain regions. However, similar to the chßactin lines, mice carrying the msprp promoter differed with respect to mesencephalic expression (fig. 5, table 1). While one line (1.3) showed strong, neuronal $\mathrm{hm}^{2}$ asyn staining in the substantia nigra (fig. 5I), the other (1.1) exhibited no neuronal staining in this region (fig. 5A). Major expression sites were the cerebral cortex, the hippocampus, the colliculi and the granular layer of the cerebellar cortex.

\section{Cellular Expression Pattern}

Two of the promoters used, the msTH and the msprp, targeted the transgene exclusively to neurons (fig. 4, 5). In contrast to these, the cellular pattern in ch $\beta$ actin lines varied from an exclusive neuronal to a more general mixed glial-neuronal pattern. In particular, three of the chßactin lines $(1.1,1.5,1.9)$ displayed numerous $\mathrm{hm}^{2}$ asyn-expressing glial cells throughout the brain (fig. 3D, H, L). 
Table 1. Expression pattern of $\mathrm{hm}^{2}$ asyn in different synTG lines

\begin{tabular}{|c|c|c|c|c|c|c|c|c|c|c|c|}
\hline \multirow{3}{*}{$\begin{array}{l}\text { Construct: } \\
\text { Transgenic line: } \\
\text { Cell types: }\end{array}$} & \multicolumn{7}{|l|}{$\operatorname{ch} \beta$ actin } & \multicolumn{2}{|l|}{ msTH } & \multicolumn{2}{|l|}{ msprp } \\
\hline & \multicolumn{2}{|l|}{1.1} & \multicolumn{2}{|l|}{1.5} & \multicolumn{2}{|l|}{1.9} & 1.10 & \multicolumn{2}{|l|}{1.2} & \multirow{2}{*}{$\frac{1.1}{\text { neurons }}$} & 1.3 \\
\hline & neurons & glia & neurons & glia & neurons & glia & neurons & neurons & neurons & & neurons \\
\hline \multicolumn{12}{|l|}{ Telencephalon } \\
\hline Olfactory bulb & - & $(+)$ & + & + & $(+)$ & + & 7 & ++ & ++ & + & + \\
\hline Striatum & - & + & + & + & + & + & ++ & $(+)$ & + & + & + \\
\hline Lateral globus pallidus & / & / & / & / & $(+)$ & + & + & - & $(+)$ & - & $(+)$ \\
\hline Nucleus accumbens & - & + & + & + & + & + & ++ & + & + & + & + \\
\hline \multicolumn{12}{|l|}{ Hippocampus (CA1) } \\
\hline Molecular layer & - & + & - & + & $(+)$ & $(+)$ & $(+)$ & - & - & $(+)$ & $(+)$ \\
\hline Pyramidal layer & + & - & + & - & ++ & - & ++ & - & - & ++ & ++ \\
\hline Multiform layer & - & + & - & + & $(+)$ & $(+)$ & ++ & - & - & $(+)$ & $(+)$ \\
\hline Hippocampus (CA2) & & & & & & & & & & & \\
\hline Molecular layer & - & $(+)$ & - & $(+)$ & $(+)$ & $(+)$ & $(+)$ & - & - & $(+)$ & $(+)$ \\
\hline Pyramidal layer & $(+)$ & - & - & - & ++ & - & ++ & - & - & + & + \\
\hline Multiform layer & - & $(+)$ & - & $(+)$ & $(+)$ & $(+)$ & ++ & - & - & $(+)$ & $(+)$ \\
\hline Hippocampus (CA3) & & & & & & & & & & & \\
\hline Molecular layer & - & $(+)$ & - & $(+)$ & $(+)$ & $(+)$ & $(+)$ & - & - & $(+)$ & $(+)$ \\
\hline Pyramidal layer & $(+)$ & - & - & - & + & - & ++ & - & - & + & ++ \\
\hline Multiform layer & - & $(+)$ & - & $(+)$ & $(+)$ & $(+)$ & ++ & - & & + & ++ \\
\hline Dentate gyrus & & & & & & & & & & & \\
\hline Molecular layer & - & ++ & - & ++ & $(+)$ & $(+)$ & $(+)$ & - & - & - & - \\
\hline Granular layer & $(+)$ & + & - & $(+)$ & ++ & - & ++ & - & - & ++ & ++ \\
\hline Multiform layer & - & $(+)$ & - & $(+)$ & $(+)$ & $(+)$ & + & - & - & $(+)$ & $(+)$ \\
\hline Subiculum & - & + & - & ++ & + & + & + & - & + & + & ++ \\
\hline Corpus callosum & - & ++ & - & ++ & - & ++ & - & - & - & - & - \\
\hline Motor cortex & $(+)$ & + & $(+)$ & + & + & + & ++ & $(+)$ & + & ++ & ++ \\
\hline Layers & $1-6$ & $1-6$ & $1-6$ & $1-6$ & $1-6$ & $1-6$ & $1-6$ & $3-6$ & $3-6$ & $1-6$ & $1-6$ \\
\hline Visual cortex & $(+)$ & ++ & $(+)$ & + & + & + & ++ & $(+)$ & + & ++ & ++ \\
\hline Layers & $1-6$ & $1-6$ & $1-6$ & $1-6$ & $1-6$ & $1-6$ & $1-6$ & $3-6$ & $3-6$ & $1-6$ & $1-6$ \\
\hline Entorhinal cortex & $(+)$ & + & - & + & - & + & + & / & $(+)$ & ++ & ++ \\
\hline Layers & $1-6$ & $1-6$ & $1-6$ & $1-6$ & $1-6$ & $1-6$ & $4-6$ & / & $5+6$ & $1-6$ & $1-6$ \\
\hline Nucleus amygdaloideus & - & $(+)$ & - & + & - & + & + & $(+)$ & + & $(+)$ & + \\
\hline Medial septal nucleus & - & $(+)$ & / & I & - & + & + & - & + & + & ++ \\
\hline Diencephalon & & & & & & & & & & & \\
\hline Thalmus & - & ++ & - & + & $(+)$ & ++ & ++ & - & - & + & + \\
\hline Hypothalmus & $(+)$ & $(+)$ & - & + & $(+)$ & ++ & + & - & $(+)$ & + & + \\
\hline Zona incerta & i & I & - & + & - & + & + & - & - & + & + \\
\hline Subthalmic nucleus & I & I & - & + & - & + & + & - & - & + & + \\
\hline Mesencephalon & & & & & & & & & & & \\
\hline Inferior colliculus & - & + & $(+)$ & ++ & $(+)$ & ++ & l & + & + & ++ & ++ \\
\hline Superior colliculus & $(+)$ & $(+)$ & - & ++ & $(+)$ & ++ & + & $(+)$ & $(+)$ & ++ & ++ \\
\hline Retrorubral field & - & $(+)$ & - & + & - & + & + & + & + & + & + \\
\hline Substantia nigra pars comp. & - & $(+)$ & - & + & - & + & + & ++ & ++ & - & + \\
\hline Substantia nigra pars reticul. & - & $(+)$ & - & $(+)$ & - & + & - & (1) & (1) & - & + \\
\hline Ventral tegmental area & - & $(+)$ & - & + & - & + & + & ++ & ++ & - & + \\
\hline Metencephalon & & & & & & & & & & & \\
\hline Locus coeruleus & - & - & - & + & + & & + & + & + & + & + \\
\hline Nuclei pontis & - & + & - & + & - & & - & - & - & + & + \\
\hline Cerebellum & & & & & & & & & & & \\
\hline Molecular layer & - & - & - & $(+)$ & - & & - & + & + & + & + \\
\hline Purkinje cell layer & + & - & + & - & ++ & & + & ++ & ++ & - & - \\
\hline Granular layer & + & - & - & + & - & & + & $(+)$ & $(+)$ & ++ & ++ \\
\hline White matter & - & - & - & + & - & & + & - & - & - & - \\
\hline Cerebellar nuclei & - & - & $(+)$ & $(+)$ & - & & - & ++ & ++ & + & + \\
\hline Myelencephalon & & & & & & & & & & & \\
\hline Motor trigeminal nuclei (V) & - & - & - & + & - & & + & - & - & - & - \\
\hline Facial nucleus (VII) & + & - & - & + & - & & + & - & - & + & + \\
\hline Nuclei formatio reticularis & $(+)$ & $(+)$ & $(+)$ & ++ & $(+)$ & & ++ & - & - & + & + \\
\hline Raphe magnus nucleus & i & i & - & + & - & & / & / & / & / & + \\
\hline
\end{tabular}


To characterize the transgene-expressing neurons further, we stained adjacent sections with sgk1 or antibodies against different neurotransmitter enzymes, respectively. With the exception of some ectopic expression sites, e.g. the GAD-immunopositive Purkinje cells (fig. 4I, J) and individual cells in other brain regions, almost all neurons in the $\mathrm{msTH}$ lines displayed the dopaminergic marker TH (fig. 4M-P). Besides the msTH lines, only one chßactin(1.10; fig. $3 \mathrm{O})$ as well as one msprp-line (1.3; fig. $5 \mathrm{G}, \mathrm{H}$, $\mathrm{M}-\mathrm{P}$ ) showed co-localization of $\mathrm{TH}$ and the transgene $\mathrm{hm}^{2}$ asyn in the nigrostriatal system.

Cellular expression of the $\mathrm{hm}^{2}$ asyn protein was strong in all TG lines. The $\mathrm{hm}^{2}$ asyn reaction product filled the somata and the processes of expressing cells. In all TG lines $\mathrm{hm}^{2}$ asyn protein was also found in the nucleus of some cells, but always spared the nucleolus (fig. 3P).

\section{Discussion}

To address the influence of promoters on the neuronal expression pattern of a transgene, we created multiple lines of TG mice expressing the doubly mutated human asyn under the control of three different promoters: the chßactin, the msTH, and the msprp promoter. In this study we have provided a detailed description of the regional distribution and the nature of the transgeneexpressing cells in the brain.

Our results demonstrate that all promoters used (i) effectively induce high transgene expression, (ii) direct the expression to the brain, and (iii) target neurons. However, the constructs used varied with respect to (i) the expression in peripheral organs, and (ii) the number and (iii) the regional distribution of expressing cells in the brain.

Western blot analysis and immunohistochemistry consistently showed that all three promoters successfully drive the expression of the transgene $\mathrm{hm}^{2}$ asyn. While the expression in the peripheral organs was variable and depended on the promoter chosen, a strong expression in the brain was constantly present in all transgenes. The widespread and strong expression of chßactin-driven transgenes is a well-known phenomenon and has been described in several reports [28-31]. Studies of the expression of endogenous prp in adult and developing mice $[32,33]$ and the expression pattern of a prp-driven transgene [34] implicate a peripheral expression of the promoter, as observed in this study. However, the results of the latter publication differed slightly from our peripheral pattern, which had strong expression in the heart, but none in the kidney. No expression was seen in the kidney, the lung, the liver and the heart using the msTH promoter.

Two of the promoters, ch $\beta$ actin and msprp, targeted almost all neurons in the brain. With the exception of few regions, $\mathrm{hm}^{2}$ syn-expressing cells were distributed throughout the entire brain. Our data are consistent with previous reports of $\beta$-actin and prp distribution in nonTG and TG mice [15, 34-36], even though they are less detailed. In contrast to ch $\beta$ actin and msprp, the $9.6-\mathrm{kb}$ msTH cassette directed the transgene specifically to a subpopulation of neurons; the catecholaminergic neurons plus some neurons that express $\mathrm{TH}$ transiently during development. The observed ectopic expression is a wellknown phenomenon found in several transgenes with the rat $\mathrm{TH}$ promoter of varying length $(4.5 \mathrm{~kb}$ up to $9 \mathrm{~kb})$ [17-19, 37-39]. Since we did not succeed in repressing an ectopic expression by the use of an even longer 9.6-kb promoter from mouse, we conclude that our promoter likewise lacks a negative element that switches off TH expression in certain cells in adulthood.

Two of the promoters, the msTH and the msprp, directed the transgene exclusively into neurons, while the chßactin promoter also induced the expression of the transgene in glial cells. The neuron-specific distribution of the prp-driven transgene is surprising, since prp is also considered to be a glial protein $[41,42]$. However, expression patterns of prp-driven transgenes are heterogeneous. While a prp-driven APP TG line exhibited astroglial expression in addition to robust neuronal expression [34], an asyn TG line exhibited an exclusive neuronal expression pattern [23]. Another remarkable and very important observation of the present study is the line-to-line variability of expression patterns in different mouse lines carrying the same construct. Every line exhibited a unique pattern of TG expression. This phenomenon was particularly prominent for the chßactin lines, where even different cell types were affected. Extremely variable patterns have before been reported for a $\operatorname{ch} \beta$ actin-driven neomycin resistance gene [43], but also for other promoters like Thy-1 [44] and prp [23]. Variability of gene expression between TG lines is due to copy number and integration site. The integration site often has profound effects, ranging from silencing to enhancement of transgene expression. Our results further indicate that the chßactin promoter is more prone to line-to-line variations than the other promoters used in this study. Conversely, the msTH $9.6 \mathrm{~kb}$ promoter induced almost identical expression patterns in different mouse lines. However, analyses of more lines are necessary to confirm this assumption. Moreover, 
because of the diversity in the integration sites, it might be expected that line-to-line variation may also result from unexpected changes in the transcription rate of endogenous genes at the integration site. All these experimental variations, arising from differences in the integration site and the number of integrated cassettes, should be considered when phenotypes of different lines with the same TG construct are compared.

Over the past years several asyn TG lines have been generated to study the involvement of asyn in PD pathogenesis and to make high-fidelity animal models resembling PD pathology. Some of them also used the promoters msprp [13, 15, 23] and msTH [17-19, 24] analyzed in this study, while a TG line using the $\beta$-actin promoter has not been reported before. Though some lines displayed at least some of the features of PD, animals with the same targeting vector from different groups generated inconsistent results. One such example are prp-driven asyn TG lines, which showed differences in neuronal pathology and in the time course of motor deficits [13, 15, 23]. This inconsistency, which might be caused by the integration process discussed above, is a major drawback of the TG approach. Targeting a TG sequence to a chosen location, e.g. by homologous recombination, may allow a more precise modelling of human disease.

In conclusion, $\mathrm{TG}$ animals offer a valuable approach to analyze pathogenesis of human diseases, and asyn transgenes driven by the TH promoter might be the most suitable models for the generation of PD pathology. However, when using the standard TG technique, one has to be aware that the results are not controlled and might be accompanied by unforeseen consequences.

\section{Acknowledgements}

This study was supported by the DFG, Graduiertenkolleg: Development and Plasticity of the Nervous System: Molecular, Synaptic and Cellular Mechanisms (L.M.). The authors thank Petra Jergolla, Holger Schlierenkamp, Katja Schmidtke, Katrin Schuster and Elisabeth Zirwes for their expert technical assistance.

\section{References}

1 Maroteaux L, Campanelli JT, Scheller RH: Synuclein: A neuron-specific protein localized to the nucleus and presynaptic nerve terminal. J Neurosci 1988;8:2804-2815.

2 Clayton DF, George JM: The synucleins: A family of proteins involved in synaptic function, plasticity, neurodegeneration and disease. Trends Neurosci 1998;21:249-254.

3 George JM: The synucleins. Genome Biol 2002;3:S3002

-4 Iwai A, Masliah E, Yoshimoto M, Ge N, Flanagan L, Rohan de Silva HA, Kittel A, Saitoh T: The precursor protein of non- $\mathrm{A} \beta$ component of Alzheimer's disease amyloid is a presynaptic protein of the central nervous system. Neuron 1995;14:467-475.

-5 Polymeropoulos MH, Higgins JJ, Golbe LI, Johnson WG, Ide SE, Di Iorio G, Sanges G, Stenroos ES, Pho LT, Schaffer AA, Lazzarini AM, Nussbaum RL, Duvoisin RC: Mapping of a gene for Parkinson's disease to chromosome 4q21-q23. Science 1996;274:1197-1199.

-6 Polymeropoulos MH, Lavedan C, Leroy E, Ide SE, Dehejia A, Dutra A, Pike B, Root H, Rubenstein J, Boyer R, Stenroos ES, Chandrasekharappa S, Athanassiadou A, Papapetropoulos T, Johnson WG, Lazzarini AM, Duvoisin RC, Di Iorio G, Golbe LI, Nussbaum RL: Mutation in the $\alpha$-synuclein gene identified in families with Parkinson's disease. Science 1997;276:2045-2047.

-7 Krüger R, Kuhn W, Müller T, Woitalla D, Graeber M, Kösel S, Przuntek H, Epplen JT, Schöls L, Riess O: Ala30 Pro mutation in the gene encoding $\alpha$-synuclein in Parkinson's disease. Nat Genet 1998;18:106-108
-8 Zarranz JJ, Alegre J, Gomez-Esteban JC, Lezcano E, Ros R, Ampuero I, Vidal L, Hoenicka J, Rodriguez O, Atares B, Llorens V, Gomez TE, del Ser T, Munoz DG, De Yebenes JG: The new mutation, E46K, of $\alpha$-synuclein causes Parkinson and Lewy body dementia. Ann Neurol 2004;55:164-173.

-9 Singleton AB, Farrer M, Johnson J, Singleton A, Hague S, Kachergus J, Hulihan M, Peuralinna T, Dutra A, Nussbaum R, Lincoln S, Crawley A, Hanson M, Maraganore D, Adler C, Cookson MR, Muenter M, Baptista M, Miller D, Blancato J, Hardy J, Gwinn-Hardy K: $\alpha$ Synuclein locus triplication causes Parkinson's disease. Science 2003;302:841.

10 Spillantini MG, Schmidt ML, Lee VMY, Trojanowski JQ, Jakes R, Goedert M: $\alpha$-Synuclein in Lewy bodies. Nature 1997;388:339-340.

11 Wakabayashi K, Matsumoto K, Takayama K, Yoshimoto M, Takahashi H: NACP, a presynaptic protein, immunoreactivity in Lewy bodies in Parkinson's disease. Neurosci Lett 1997; 239:45-48

12 Krüger R, Menezes Vieira-Saecker AM, Kuhn W, Berg D, Müller T, Kühnl N, Fuchs GA, Storch A, Hungs M, Woitalla D, Przuntek H, Epplen JT, Schöls L, Riess O: Increased susceptibility to sporadic Parkinson's disease by a certain combined $\alpha$-synuclein/apolipoprotein E genotype. Ann Neurol 1999;45:611-617.

13 Giasson BI, Duda JE, Quinn SM, Zhang B, Trojanowski JQ, Lee VM: Neuronal $\alpha$-synucleinopathy with severe movement disorder in mice expressing A53T human a-synuclein. Neuron 2002;34:521-533.
14 Kahle PJ, Neumann M, Ozmen L, Müller V, Jacobsen H, Schindzielorz A, Okochi M, Leimer U, van der Putten H, Probst A, Kremmer E, Kretzschmar HA, Haass C: Subcellular localization of wild-type and Parkinson's diseaseassociated mutant $\alpha$-synuclein in human and transgenic mouse brain. J Neurosci 2000;20: 6365-6373.

15 Lee MK, Stirling W, Xu Y, Xu X, Qui D, Mandir AS, Dawson TM, Copeland NG, Jenkins NA, Price DL: Human $\alpha$-synuclein-harboring familial Parkinson's disease-linked Ala$53 \rightarrow \mathrm{Thr}$ mutation causes neurodegenerative disease with $\alpha$-synuclein aggregation in transgenic mice. Proc Natl Acad Sci USA 2002;99: 8968-8973.

16 Masliah E, Rockenstein E, Veinbergs I, Mallory M, Hashimoto M, Takeda A, Sagara Y, Sisk A, Mucke L: Dopaminergic loss and inclusion body formation in $\alpha$-synuclein mice: Implications for neurodegenerative disorders. Science 2000;287:1265-1269.

17 Matsuoka Y, Vila M, Lincoln S, McCormack A, Picciano M, LaFrancois J, Yu X, Dickson D, Langston WJ, McGowan E, Farrer M, Hardy J, Duff K, Przedborski S, Di Monte D: Lack of nigral pathology in transgenic mice expressing human $\alpha$-synuclein driven by the tyrosine hydroxylase promoter. Neurobiol Dis 2001;8: 535-539.

18 Rathke-Hartlieb S, Kahle PJ, Neumann M, Ozmen L, Haid S, Okochi M, Haass C, Schulz JB: Sensitivity to MPTP is not increased in Parkinson's disease-associated mutant $\alpha$-synuclein transgenic mice. J Neurochem 2001;77:11811184 
19 Richfield EK, Thiruchelvam MJ, Cory-Slechta DA, Wuertzer C, Gainetdinov RR, Caron MG, Di Monte DA, Federoff HJ: Behavioral and neurochemical effects of wild-type and mutated human $\alpha$-synuclein in transgenic mice. Exp Neurol 2002;175:35-48.

20 Van der Putten H, Wiederhold KH, Probst A Barbieri S, Mistl C, Danner S, Kauffmann S, Hofele K, Spooren WP, Ruegg MA, Lin S, Caroni P, Sommer B, Tolnay M, Bilbe G: Neuropathology in mice expressing human $\alpha$-synuclein. J Neurosci 2000;20:6021-6029.

$\checkmark 21$ Rockenstein E, Mallory M, Hashimoto M, Song D, Shults CW, Lang I, Masliah E: Differential neuropathological alterations in transgenic mice expressing $\alpha$-synuclein from the platelet-derived growth factor and Thy-1 promoters. J Neurosci Res 2002;68:568-578.

22 Gomez-Isla T, Irizarry MC, Mariash A, Cheung B, Soto O, Schrump S, Sondel J, Kotilinek L, Day J, Schwarzschild MA, Cha JH, Newell K, Miller DW, Ueda K, Young AB, Hyman BT, Ashe KH: Motor dysfunction and gliosis with preserved dopaminergic markers in human $\alpha$-synuclein A30P transgenic mice. Neurobiol Aging 2003;24:245-258.

$\checkmark 23$ Gispert S, Del Turco D, Garrett L, Chen A, Bernard D J, Hamm-Clement J, Korf H W, Deller T, Braak H, Auburger G, Nussbaum RL: Transgenic mice expressing mutant A53T human $\alpha$-synuclein show neuronal dysfunction in the absence of aggregate formation. Mol Cel Neurosci 2003;24:419-429.

24 Thiruchelvam MJ, Powers JM, Cory-Slechta DA, Richfield EK: Risk factors for dopaminergic neuron loss in human $\alpha$-synuclein transgenic mice. Eur J Neurosci 2004;19:845-854.

$\checkmark 25$ Neuhoff VPK, Zimmer HG, Mesecke S: A simple and versatile, sensitive and volume-independent method for quantitative protein determination with independence of other externa influences. Hoppe Seylers Z Physiol Chem 1979;360:1657-1670.

-26 Stichel CC, Singer W, Zilles K: Ultrastructure of $\mathrm{PkC}$ (II/III)-immunopositive structures in rat primary visual cortex. Exp Brain Res 1990;82: 575-584.
27 Paxinos G, Franklin KBJ, The Mouse Brain in Stereotaxic Coordinates. San Diego, Academic Press, 2001.

28 Marber MS, Mestril R, Chi SH, Sayen MR, Yellon DM, Dillmann WH: Overexpression of the rat inducible $70-\mathrm{kD}$ heat stress protein in a transgenic mouse increases the resistance of the heart to ischemic injury. J Clin Invest 1995;95: 1446-1456.

29 Ho YS: Transgenic and knockout models for studying the role of lung antioxidant enzymes in defense against hyperoxia. Am J Respir Crit Care Med 2002;166:S51-S56.

30 Kosuga M, Enosawa S, Li XK, Suzuki S, Matsuo N, Yamada M, Roy-Chowdhury J, Koiwai O, Okuyama T: Strong, long-term transgene expression in rat liver using chicken $\beta$-actin promoter associated with cytomegalovirus immediate-early enhancer (CAG promoter). Cell Transplant 2000;9:675-680.

31 Seng S, Yokoyama M, Suzuki R, Maki Y, Kato M, Lim C, Zayatiin B, Inoue N, Xuan X, Igarashi I, Nagasawa H, Fujisaki K, Mikami T, Suzuki N, Toyoda Y: Expression of SAG-1 of Toxoplasma gondii in transgenic mice. Parasitol Res 2000;86:263-269.

>32 Manson J, West JD, Thomson V, McBride P, Kaufman MH, Hope J: The prion protein gene: A role in mouse embryogenesis? Development 1992; 115:117-122.

33 Ford MJ, Burton LJ, Morris RJ, Hall SM: Selective expression of prion protein in peripheral tissues of the adult mouse. Neuroscience 2002;113:177-192.

34 Borchelt DR, Davis J, Fischer M, Lee MK, Slunt HH, Ratovitsky T, Regard J, Copeland NG, Jenkins NA, Sisodia SS, Price DL: A vector for expressing foreign genes in the brains and hearts of transgenic mice. Genet Anal 1996;13:159-163.

35 Liu T, Zwingmann T, Li R, Pan T, Wong BS, Petersen RB, Gambetti P, Herrup K, Sy MS: Differential expression of cellular prion protein in mouse brain as detected with multiple antiPrP monoclonal antibodies. Brain Res 2001; 896:118-129.
36 Kaech S, Fischer M, Doll T, Matus A: Isoform specificity in the relationship of actin to dendritic spines. J Neurosci 1997;17:9565-9572.

37 Schimmel JJ, Crews L, Roffler-Tarlov S, Chikaraishi DM: $4.5 \mathrm{~kb}$ of the rat tyrosine hydroxylase 5'-flanking sequence directs tissue-specific expression during development and contains consensus sites for multiple transcription factors. Mol Brain Res 1999;74:1-14.

38 Banerjee SA, Roffler-Tarlov S, Szabo M, Frohman L, Chikaraishi DM: DNA regulatory sequences of the rat tyrosine hydroxylase gene direct correct catecholaminergic cell-type specificity of a human growth hormone reporter in the CNS of transgenic mice causing a dwarf phenotype. Mol Brain Res 1994;24:89-106.

39 Son JH, Min N, Joh TH: Early ontogeny of catecholaminergic cell lineage in brain and peripheral neurons monitored by tyrosine hydroxylase-lacZ transgene. Brain Res Mol Brain Res 1996;36:300-308.

40 Min N, Joh TH, Kim KS, Peng C, Son JH: 5' upstream DNA sequence of the rat tyrosine hydroxylase gene directs high-level and tissuespecific expression to catecholaminergic neurons in the central nervous system of transgenic mice. Brain Res Mol Brain Res 1994;27:281289.

41 Moser M, Colello RJ, Pott U, Oesch B: Developmental expression of the prion protein gene in glial cells. Neuron 1995;14:509-517.

42 Verghese-Nikolakaki S, Michaloudi H, Polymenidou M, Groschup MH, Papadopoulos GC, Sklaviadis T: Expression of the prion protein in the rat forebrain - An immunohistochemical study. Neurosci Lett 1999;272:9-12.

43 Bronson SK, Plaehn EG, Kluckman KD, Hagaman JR, Maeda N, Smithies O: Single-copy transgenic mice with chosen-site integration. Proc Natl Acad Sci USA 1996;93:9067-9072.

44 Andrä K, Abramowski D, Duke M, Probst A, Wiederhold K-H, Bürki K, Goedert M, Sommer B, Staufenbiel M: Expression of APP in transgenic mice: A comparison of neuron-specific promoters. Neurobiol Aging 1996;17: 183-190. 